\title{
Living in a same microhabitat should means eating the same food? Diet and trophic niche of sympatric leaf-litter frogs Ischnocnema henselii and Adenomera marmorata in a forest of Southern Brazil
}

\author{
Santos-Pereira, M. ${ }^{a *}$, Almeida-Santos, M. ${ }^{a}$, Oliveira, FB. ${ }^{b}$, Silva, AL. ${ }^{a}$ and Rocha, CFD. ${ }^{a}$ \\ ${ }^{\text {a }}$ Departamento de Ecologia, Instituto de Biologia Roberto Alcântara Gomes, Universidade do Estado do \\ Rio de Janeiro - UERJ, Rua São Francisco Xavier, 524, CEP 20550-013, Rio de Janeiro, RJ, Brazil

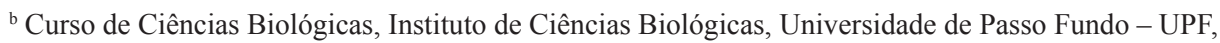 \\ Campus I, BR 285, CEP 99001-970, Passo Fundo, RS, Brazil \\ *e-mail: herpeto.pereira@gmail.com
}

Received: September 4, 2013 - Accepted: January 6, 2014 - Distributed: March 31, 2015

(With 1 figure)

\begin{abstract}
In this study we analyzed diet composition, niche breadth and overlap of the two leaf-litter frogs Ischnocnema henselii and Adenomera marmorata. Frogs were collected in an Atlantic Rainforest area in the Reserva Natural Salto Morato, in Paraná State, Southern Brazil, using plots of $16 \mathrm{~m}^{2}$ established on forest floor. Ischnocnema henselii consumed 18 different types of prey and the diet of this species was composed predominantly by Hymenoptera (Formicidae) (15.4\%), Araneae (13.83\%), Orthoptera (6.15\%) and Opiliones (6.15\%), whereas Adenomera marmorata consumed 15 different types of prey and its diet was composed mainly by Hymenoptera (Formicidae) (45.7\%), Acari (31.8\%) and Blattodea (14.8\%). The niche breadth of $I$. henselii was $\mathrm{B}_{\mathrm{A}}=0.43$ and that of $A$. marmorata was $\mathrm{B}_{\mathrm{A}}=0.19$. The diet of the two sympatric species of leaf-litter frogs was basically composed by arthropods and the trophic niche overlap among them did not differ from expected at random. The differences in prey consumption should potentially facilitate the coexistence of two sympatric frogs on the forest floor. Possibly, this difference of prey consumption partly reflects differences in jaw width, species-specific body size of the two species and the period of activity of these two species.
\end{abstract}

Keywords: Anura, syntopy, species coexistence, Atlantic Rainforest.

\section{Viver no mesmo ambiente significa comer o mesmo alimento? Dieta e nicho trófico dos anuros simpátricos de folhiço Ischnocnema henselii e Adenomera marmorata em uma floresta do sul do Brasil}

\begin{abstract}
Resumo
Neste estudo analisamos a composição da dieta e a amplitude e sobreposição do nicho trófico dos anuros de folhiço Ischnocnema henselii e Adenomera marmorata. Os anuros foram coletados em uma área de Mata Atlântica na Reserva Natural Salto Morato, no Estado do Paraná, Sul do Brasil, utilizando o método de parcelas de $16 \mathrm{~m}^{2}$ estabelecidas no chão da floresta. Ischnocnema henselii consumiu 18 diferentes tipos de presa e a dieta desta espécie foi composta predominantemente por Hymenoptera (Formicidae) (15,4\%), Araneae (13,83\%), Orthoptera (6,15\%) e Opiliones $(6,15 \%)$, enquanto Adenomera marmorata consumiu 15 diferentes tipos de presas e sua dieta foi composta principalmente por Hymenoptera (Formicidae) (45,7\%), Acari (31,8\%) e Blattodea (14,8\%). A amplitude de nicho de $I$. henselii foi $\mathrm{B}_{\mathrm{A}}=0,43$ e de A.marmorata foi $\mathrm{B}_{\mathrm{A}}=0,19$. A dieta das duas espécies de anuros simpátricos do folhiço por nós estudadas foi composta basicamente de artrópodes e a sobreposição de nicho trófico entre elas não diferiu do esperado para ocorrer ao acaso. As diferenças no consumo de presas potencialmente devem facilitar a coexistência desses dois anuros simpátricos no chão da floresta. Possivelmente, esta diferença no consumo de presas em parte reflete diferenças na largura da mandíbula, no tamanho do corpo e no período de atividade dessas duas espécies.
\end{abstract}

Palavras-chave: Anura, sintopia, coexistência de espécies, Mata Atlântica.

\section{Introduction}

The coexistence of similar species within a community implies in temporal and spatial overlap between these species. This coexistence could not occur if two or more

species compete for a single limiting resource ("Competitive Exclusion Principle"; Hardin, 1960). Therefore, ecological differences, or niche differences, are necessary to allow 
coexistence among species. Despite niche are known to contain several dimensions, its main dimensions are daily activity (time), microhabitat use (space) and food resources (diet) (Pianka, 1994).

Food is a crucial resource for animals and its partitioning among sympatric and syntopic species is an important tool to understand interactions among locally coexisting species (Schoener, 1974; Taper and Marquet, 1996; Sih and Christensen, 2001). Trophic niche overlap occurs when two species share similar food resource when exploiting the habitat. However, in nature, usually only a partial overlap tend to occur where some resources are shared and other are used exclusively by each one of the species (Pianka, 1994). Therefore, sympatric species do not necessarily feed on the same items due to the differences in their evolutionary history (phylogenetic affinities), patterns of microhabitat use (Van Sluys and Rocha, 1998), intrinsic ecological aspects (e.g. ecophysiology), body size (Sabagh et al.,2010) which, as result, may lead to the consumption of prey of different sizes, types and also to forage at different periods (Menin et al., 2005).

Ischnocnema henselii (Peters, 1870) (Brachycephalidae) and Adenomera marmorata (Steindachner, 1867) (Leptodactylidae) are endemic to the Brazilian Atlantic Rainforest biome, occurring in sympatry in various parts of this biome (Frost, 2013). The two species sharing nocturnal activity (whilst $A$. marmorata is also active in daylight period), being $I$. henselii slightly larger than A. marmorata in body size (Haddad et al., 2013). In Paraná State, Southern Brazil, these two leaf litter frogs are usually the most abundant species and occur syntopically on the forest floor of the Atlantic Rainforest of Reserva Natural Salto Morato (Santos-Pereira et al., 2011).

In this study, we analyzed the diet aspects, niche breadth, and niche overlap of Ischnocnema henselii and Adenomera marmorata, specifically aiming to answer the following questions: 1) What is the composition of the diet and food niche breadth of the two studied species? 2) To what extent does the width of the frog jaw explain the size of prey ingested? 3) How the sympatric frogs species differ in body size? 4) In which extent do the syntopic frogs overlap in their trophic niche?

\section{Material and Methods}

Frogs were collected between January and April 2010 in an Atlantic Rainforest area in the Reserva Natural Salto Morato (25 $09^{\prime}$ S; $48^{\circ} 16^{\prime}$ to $\left.48^{\circ} 20^{\prime} \mathrm{W}\right)$, in Paraná State, Southern Brazil. The reserve has an area of 2,252 ha, located in the Área de Preservação Ambiental de Guaraqueçaba, and it is part of the largest and continuous remnant of the Atlantic Rainforest in Brazil (Câmara, 2005). The mean annual temperature is $21^{\circ} \mathrm{C}$ and the mean annual relative humidity is $85 \%$. The altitude varies between $25-930$ m.a.s.1., and the rainfall is about 2,000 mm per year (FBPN, 2011).

To sample the anurans species, we used Large-Plot sampling method (Jaeger and Inger, 1994). We established 88 plots of $16 \mathrm{~m}^{2}(4 \times 4 \mathrm{~m})$ on the forest floor, totaling
$1,408 \mathrm{~m}^{2}$ of sampled area. Plots were arbitrarily established scattered along the forest floor at altitudes from 200 to 300 m.a.s.l. in an area of primary Atlantic Rainforest. We marked the corners of each plot with plastic stakes, and the area inside the plot was enclosed with a $50 \mathrm{~cm}$ high soft plastic fence. At night, each plot was carefully searched for about half an hour by a team of four persons using headlamps. The plots were established at least 100 meters away from each other, in order to avoid spatial pseudoreplication of data. Frogs were anesthetized with lidocaine, killed in $50 \%$ ethanol, fixed in $10 \%$ formalin and preserved in $70 \%$ ethanol.

Voucher specimens from this study were deposited at the scientific collection of the Museu Nacional do Rio de Janeiro under the following numbers (I. henselii: MNRJ 75394-75400 and MNRJ 75418-75438 and A. marmorata: MNRJ 75439-75460).

In the laboratory, individuals had the snout-vent length (SVL) and the jaw size (LM) measured (both in $\mathrm{mm}$ ) with a digital caliper (to the nearest $0.1 \mathrm{~mm}$ ). Frogs were dissected and their stomach contents were qualitatively and quantitatively analyzed. Animal prey was identified under a dissecting stereoscopic microscope to the taxonomic level of order, except in the case of ants (identified to Family), molluscs, millipedes and centipedes, which were identified to Class (Triplehorn and Johnson, 2005). For each food item, we measured the length and the width using calipers $(0.1 \mathrm{~mm}$ precision $)$ and prey volume $\left(\mathrm{mm}^{3}\right)$ was estimated using the formula for an ovoid spheroid: $V=4 / 3 \pi$ (length/2) (width/2) $)^{2}$ (Dunham, 1983). Unidentified remains of arthropods were grouped as "remains of arthropods" and this category was considered only for volumetric analysis. The frequency for each category of prey was expressed by the number of stomachs that contained that category. An index of relative importance $(I x)$ was calculated for each prey category, with the sum of the numeric, volumetric and frequency of occurrence proportions divided by three (Powell et al., 1990).

We estimated the trophic niche breadth (based on the number of food items) using the formula proposed by Levins (1968). The values of niche breadth were standardized $\left(B_{A}\right)$ to the range of 0 to 1 using the appropriated formula. We calculated the niche overlap between the two species $\left(\mathrm{O}_{\mathrm{jk}}\right.$, based on the $I x$ ) using the formula of MacArthur and Levins (1967) modified by Pianka (1973). This index value varies from 0 (total partitioning) to 1 (total overlap). We tested if the probability of trophic niche overlap would be the same if data would be randomly distributed using null models (with 10.000 iterations or pseudo-communities), with the software EcoSim (Gotelli and Entsminger, 2006). For the analysis we utilized a matrix containing the importance index (Ix) of each category of species's prey. We used the algorithm of randomization number three (RA3), that consider each species resource, effectively retaining the niche breadth of species (Gotelli and Graves, 1996). Differences among frog species in body size (SVL) were evaluated using a T-test (Zar, 1999). We performed a simple linear regression between prey size (based on the 
volume of the largest prey) and jaw width to evaluate in which extent jaw width of individuals influenced the size of consumed prey.

\section{Results}

From the 88 plots sampled, Ischnocnema henselii and Adenomera marmorata occurred in 36 of them, but they co-occurred in only five plots $(14 \%)$. In the summer the two frog species occurred in 28 plots whereas in the autumn they occurred in eight plots. All of the plots that the two species occurred together were sampled in the summer.

Ischnocnema henselii $(\mathrm{n}=28)$ consumed 18 different prey types and $7.1 \%$ of sampled individuals had empty stomachs $(\mathrm{n}=2)$. Formicidae (Hymenoptera) $(15.4 \%)$ was the dominant item in the diet of I. henselii in terms of number, followed by Araneae (13.8\%) and Opiliones and Orthoptera (both with 6.2\%). In terms of volume, Orthoptera (14.3\%) dominated, followed by Blattodea (6.5\%) and Formicidae (3.0\%). Araneae was the most frequent item
(25\%), followed by Formicidae (21.4\%), and Orthoptera and Opiliones (both with 14.3\%). Based on the index of importance (Ix), Araneae (12.3\%), Formicidae (12.1\%) and Orthoptera $(11.1 \%)$ were the most representative items in the diet of I. henselii (Table 1).

Adenomera marmorata $(\mathrm{n}=22)$ consumed 15 different types of prey items and all frogs had some content in their stomach. Formicidae (45.7\%) was the dominant item by number, followed by Acari (31.5\%) and Diplopoda (5.4\%). Blattodea represented $19.1 \%$ of total volume intake, followed by Formicidae (8.7\%) and Isopoda (4.6\%). Formicidae was also the more frequent item $(86.4 \%)$, followed by Acari (59.1\%) and Hymenoptera and Blattodea, both with $22.7 \%$. According to the index of importance $(I x)$, Formicidae (45.7\%), Acari (31.08\%) and Blattodea (14.8\%) were the most representative preys with the other items being less frequent in the diet of $A$. marmorata (Table 1).

The prey items shared the two frog species were: Amphipoda, Araneae, Blattodea, Colembola, Coleoptera

Table 1. Number (N), Volume (V, in $\left.\mathrm{mm}^{3}\right)$, Frequency $(\mathrm{F})$ and Importance index (Ix) of the different prey types in the diet of Ischnocnema henselii $(\mathrm{n}=28)$ and Adenomera marmorata $(\mathrm{n}=22)$ at RPPN Salto Morato, Southern Brazil. (URA) Unidentified remains of arthropods.

\begin{tabular}{|c|c|c|c|c|c|c|c|c|}
\hline \multirow[t]{2}{*}{ PREY TYPES } & \multirow{2}{*}{$\begin{array}{c}\begin{array}{c}\text { Ischnocnema } \\
\text { henselii }\end{array} \\
\mathbf{N} \% \\
\end{array}$} & \multirow{2}{*}{$\begin{array}{c}\begin{array}{c}\text { Adenomera } \\
\text { marmorata }\end{array} \\
\mathrm{V} \% \\
\end{array}$} & \multirow[b]{2}{*}{ F\% } & \multirow[b]{2}{*}{$\mathbf{I x}$} & \multirow[b]{2}{*}{ N\% } & \multirow[b]{2}{*}{$V \%$} & \multirow[b]{2}{*}{ F\% } & \multirow[b]{2}{*}{$\mathbf{I x}$} \\
\hline & & & & & & & & \\
\hline Acari & - & - & - & - & 34.59 & 1.70 & 59.09 & 31.79 \\
\hline Araneae & 13.85 & 1.37 & 25.00 & 13.40 & 2.16 & 0.30 & 18.18 & 6.88 \\
\hline Opiliones & 6.15 & 2.50 & 14.29 & 7.65 & 1.08 & 0.39 & 9.09 & 3.52 \\
\hline Chilopoda & 1.54 & 0.46 & 3.57 & 1.86 & - & - & - & - \\
\hline Diplopoda & - & - & - & - & 5.41 & 3.98 & 9.09 & 6.16 \\
\hline Malacostraca & 1.54 & 0.01 & 3.57 & 1.71 & - & - & - & - \\
\hline Amphipoda & 1.54 & 1.55 & 3.57 & 2.22 & 0.54 & 0.18 & 4.55 & 1.76 \\
\hline Isopoda & 1.54 & 1.43 & 3.57 & 2.18 & 0.54 & 4.64 & 4.55 & 3.24 \\
\hline Colembola & 4.62 & 0.04 & 10.71 & 5.12 & 0.54 & 0.06 & 4.55 & 1.72 \\
\hline Orthoptera & 6.15 & 14.25 & 14.29 & 11.56 & - & - & - & - \\
\hline Isoptera & - & - & - & - & 3.24 & 0.08 & 9.09 & 4.14 \\
\hline Blattodea & 3.08 & 6.54 & 7.14 & 5.59 & 2.70 & 19.12 & 22.73 & 14.85 \\
\hline \multicolumn{9}{|l|}{ Hemiptera } \\
\hline adults & 3.08 & 0.40 & 3.57 & 2.35 & 0.54 & 0.07 & 4.55 & 1.72 \\
\hline nymphs & 1.54 & 0.19 & 3.57 & 1.77 & - & - & - & - \\
\hline \multicolumn{9}{|l|}{ Coleoptera } \\
\hline adults & 3.08 & 1.21 & 7.14 & 3.81 & 1.62 & 0.37 & 13.64 & 5.21 \\
\hline larvae & 1.54 & 0.01 & 3.57 & 1.71 & - & - & - & - \\
\hline Hymenoptera & - & - & - & - & 3.78 & 0.64 & 22.73 & 9.05 \\
\hline Hymenoptera (Formicidae) & 15.38 & 3.01 & 21.43 & 13.27 & 42.16 & 8.66 & 86.36 & 45.73 \\
\hline \multicolumn{9}{|l|}{ Lepidoptera } \\
\hline adults & 1.54 & 0.06 & 3.57 & 1.72 & - & - & - & - \\
\hline larvae & 1.54 & 2.86 & 3.57 & 3.57 & - & - & - & - \\
\hline \multicolumn{9}{|l|}{ Diptera } \\
\hline adults & 1.54 & 0.09 & 3.57 & 1.73 & 0.54 & 0.06 & 4.55 & 1.72 \\
\hline larvae & 1.54 & 0.14 & 3.57 & 1.75 & - & - & - & - \\
\hline Mollusca & - & - & - & - & 0.54 & 0.02 & 4.55 & 1.70 \\
\hline Plant material & 1.54 & 0.03 & 3.57 & 3.57 & - & - & - & - \\
\hline URA & - & 63.85 & - & - & - & 59.73 & - & - \\
\hline
\end{tabular}


(adults), Diptera (adults), Formicidae, Isopoda, Mollusca and Opiliones. Items exclusively consumed by I. henselii were Chilopoda, Coleoptera (larvae), Diptera (larvae), Hemiptera (nymphs), Lepidoptera (adults and larvae) and Orthoptera. Acari, Diplopoda, Hymenoptera and Isoptera were prey items consumed exclusively by $A$. marmorata (Table 1). Arthropod preys with large body size were crickets and Araneae whereas those with small size were Acari and Collembola.

The niche breadth of $I$. henselii was $\mathrm{B}_{\mathrm{A}}=0.43$ and that of $A$. marmorat was $\mathrm{B}_{\mathrm{A}}=0.19$. The mean SVL of $I$. henselii $(27.4 \pm 4.5 \mathrm{~mm}$; range: $8.55-39.93 \mathrm{~mm})$ was significantly larger than that of $A$. marmorata $(16.9 \pm 3.5 \mathrm{~mm}$; range: $8.78-21.08)\left(\mathrm{t}\right.$-test, $\left.\mathrm{t}_{\mathrm{svl}}=3.528 ; \mathrm{df}=48 ; \mathrm{p}=0.001\right)$. In both species the jaw size significantly influenced the maximum volume of prey ingested (I. henselii: mean $=7.6 \pm 2.7 \mathrm{~mm}$; range: $2.58-14.06 \mathrm{~mm} ; \mathrm{F}_{1.21}=9.487, \mathrm{R}^{2}=0.558, \mathrm{p}=0.006$ and A.marmorata: mean $=3.97 \pm 1.24 \mathrm{~mm}$; range: $\left.2.19-5.71 \mathrm{~mm} ; \mathrm{F}_{1.20}=10.563, \mathrm{R}^{2}=0.588, \mathrm{p}=0.004\right)$ (Figure 1). Niche overlap among species was $\mathrm{O}_{\mathrm{jk}} 0.52$. The mean observed was higher than expected $\left(\Phi_{\mathrm{obs}}=0.52\right.$; $\left.\Phi_{\text {exp }}=0.32 ; p_{\text {obs }} \leq \mathrm{p}_{\text {exp }}=0.90 ; \mathrm{p}_{\text {obs }} \geq \mathrm{p}_{\text {exp }}=0.09\right)$, and did not differ from expected by random.

\section{Discussion}

Our results suggested that even living in syntopy in forest floor, and possibly being exposed to a similar set of prey, Ischnocnema henselii and Adenomera marmorata differed in some aspects of their diet. Although the two species fed on a similar number of prey types (I. henselii $=$ 18 and $A$. marmorata $=15$ different prey types), differences in the types of the consumed items may have contributed to

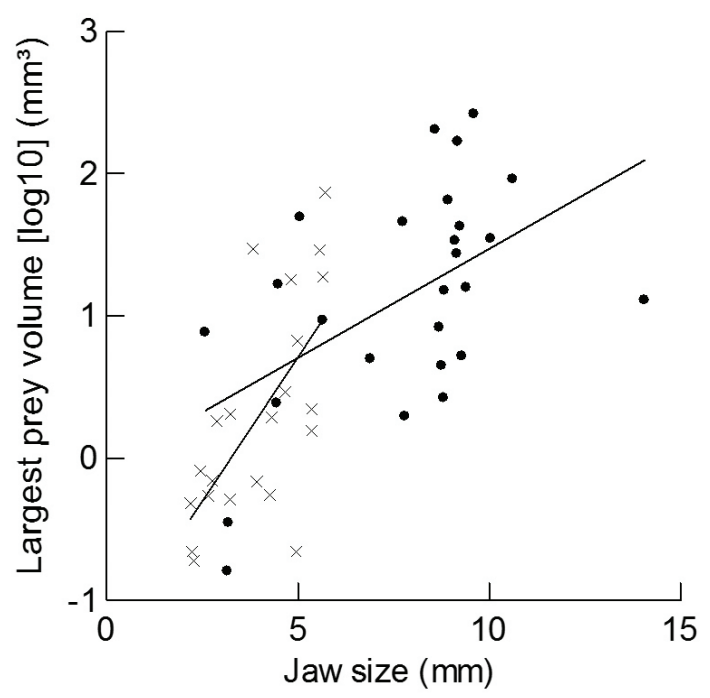

Figure 1. Relationship between jaw width $(\mathrm{mm})$ and largest prey volume in $\log 10\left(\mathrm{~mm}^{3}\right)$ of food items ingested by Adenomera marmorata (gray symbol) and Ischnocnema henselii (black symbol) in Reserva Natural Salto Morato, Paraná State. the observed differences in their diets. Although for many frog species, the diet tend to simply reflect the availability of prey in the environment (Duellman and Trueb, 1994), other factors may also influence the consumption of preys by frogs. Sabagh et al. (2010) studied food consumption by two syntopic hylid species in Central Brazil and suggested that some intrinsic ecological aspects (e.g. ecophysiology), tended to result in differences in the types of prey eaten and in their consumption frequencies. Differences in body size may also explain differences in the rate and type of preys consumed by syntopic frogs (Van Sluys and Rocha, 1998).

In the present study, Araneae, Formicidae and Orthoptera were the most important preys to I. henselii, whereas Formicidae, Acari and Blattodea were the most important prey items for A. marmorata. This result can be partially explained by the larger size of $I$. henselii, which allow the consumption of preys of comparatively larger sizes, as spiders and crickets. On the other hand, the importance of Acari consumed by A. marmorata may reflect the comparatively smaller body size of this frog, which may favor the consumption of small preys. Only Ischnocnema henselii consumed Orthoptera (large prey), while solely $A$. marmorata ate Acari (small prey). These preys consumed exclusively for each species possibly contributed to the coexistence of these species of leaflitter frogs.

Although leptodactylids are not considered important predators of mites species in the leaf-litter (Simon and Toft, 1991), this item can be an important food resource to smaller species, as recorded for Adenomera andreae in the Central Amazon (Lima, 1998), for Zachaenus parvulus in the Atlantic Forest (Van Sluys et al., 2001), also for miniaturized frog species such as Brachycephalus didactylus (Almeida-Santos et al., 2011) and for Ischnochnema parva (Martins et al., 2010), another frog species that inhabit the leaf-litter. We demonstrated that $A$. marmorata had a higher consumption of ants in terms of number $(42.2 \%)$, frequency (86.4\%) and importance (45.7\%), compared to I. henselii $(\mathrm{N}=15.4 ; \mathrm{F}=21.4 ; \mathrm{Ix}=13.3)$, what was not expected for a leptodactylid considered as non-ant-specialist guild (sensu Toft, 1980). However, our results reinforce the idea that this generalization may not apply to A. marmorata species group, since ants form a substantial part of its diet, as was also reported by Almeida-Gomes et al. (2007). In the Amazon, the consumption of ants by Adenomera andreae by adult individuals was also higher (Sabagh et al., 2012), whereas for small individuals the proportion of mites dominated (Pimentel Lima and Magnusson, 1998). As argued by Toft (1980), ant-specialist species tend to eat slower and chitinous prey, whereas those who are non-ant-specialists tend to eat faster-moving prey such as cockroaches, crickets and spiders. Ischnocnema henselii showed a comparatively lower consumption of ants and may be considered a non-ant-specialist (sensu Toft, 1980). It consumed higher amount of fast-moving prey, compared to A. marmorata. On the other hand, it has been shown that ants have a high biomass in tropical rainforests (Hölldobler 
and Wilson, 1990), which also may explain the importance of the consumption of these arthropods.

We conclude that the diet of the two syntopic species of leaf-litter frogs studied were composed basically of arthropod preys and that the observed niche overlap did not differ from expected at random. Concurrently, the distinct size of preys ingested (larger in Ischnocnema henselii), the differences in trophic niche breadth (greater in I. henselii) and the occurrence of exclusive prey categories (Orthoptera by $I$. henselii and Acari by A. marmorata) among the three more important items consumed, all these factors might explain the coexistence of these two frogs on the forest floor at Reserva Natural Salto Morato. These differences in prey consumption may be due to differences in jaw and body size of these species, as well, differences in activity period (broader in A. marmorata). Thus, even living in the same habitat and sharing a specific microhabitat, leaf-litter frogs from Atlantic Rainforest can feed on different things.

\section{Acknowledgements}

This study was supported by research grants from the Conselho Nacional de Desenvolvimento Científico e Tecnológico (CNPq) (\#304791/2010-5 and 470265/2010-8) and from the Fundação de Amparo à Pesquisa do Estado do Rio de Janeiro (FAPERJ) through "Cientistas do Nosso Estado" Program (E-26/102.765/2012) to CFDR. Graduate fellowships were granted to MSP from the Coordenação de Aperfeiçoamento de Pessoal de Nivel Superior (CAPES). Financial support for the realization of the project was granted by Fundação Grupo Boticário de Proteção à Natureza (FBPN), through the Reserva Natural Salto Morato (Term Partnership n ${ }^{\circ} 0165 \_2012$ PR). Authorization (No. 20703-3) to collect the frogs was granted by Instituto Chico Mendes de Conservação da Biodiversidade (ICMBio). We thank DC. Passos and LT. Sabagh, which kindly reviewed a draft version offering valuable suggestions.

\section{References}

ALMEIDA-GOMES, M., VAN SLUYS, M. and ROCHA, CFD., 2007. Ecological observations on the leaf-litter frog Adenomera marmorata in an Atlantic rainforest area of southeastern Brazil. The Herpetological Journal, vol. 17, p. 81-85.

ALMEIDA-SANTOS, M., SIQUEIRA, CC., VAN SLUYS, M. and ROCHA, CFD., 2011. Ecology of the Brazilian Flea Frog Brachycephalus didactylus (Terrarana: Brachycephalidae). Journal of Herpetology, vol. 45, no. 2, p. 251-255. http://dx.doi. org/10.1670/10-015.1.

CÂMARA, IG., 2005. Breve história da conservação da Mata Atlântica. In GALINDO-LEAL, C. and CÂMARA, IG. (Eds.). Mata Atlântica: Biodiversidade, ameaças e perspectivas. São Paulo: Fundação SOS Mata Atlântica; Belo Horizonte: Conservação Internacional. p. 31-42.

DUELLMAN, WE. and TRUEB, L., 1994. Biology of Amphibians. Baltimore: The Johns Hopkins University Press. 670 p.

DUNHAM, AE., 1983. Realized niche overlap, resource abundance, and intensity of interspecific competition. In HUEY, RB., PIANKA,
ER. and SCHOENER, TW. (Eds.). Lizard ecology: studies of a model organism. Cambridge: Harvard University Press. p. 261-280. http://dx.doi.org/10.4159/harvard.9780674183384.c15.

Fundação Grupo Boticário de Proteção à Natureza - FBPN, 2011. Plano de Manejo da Reserva Natural Salto Morato Guaraqueçaba - PR. Curitiba: Fundação Grupo Boticário de Proteção à Natureza. 222 p. vol. 1.

FROST, DR., 2013. Amphibian Species of the World: an Online Reference. New York: American Museum of Natural History. Available from: $<\mathrm{http}: / /$ research.amnh.org/herpetology/amphibia/ index.html>. Access in: 9 Jan. 2013.

GOTELLI, NJ. and ENTSMINGER, GL., 2006. EcoSim: null models software for ecology. Jericho: Acquired Intelligence Inc. and Kesey-Bear.

GOTELLI, NJ. and GRAVES, GR., 1996. Null models in Ecology. Washington: Smithsonian Institute. 368 p.

HADDAD, CFB., TOLEDO, LF., PRADO, CPA., LOEBMANN, D., GASPARINI, JL. and SAZIMA, I., 2013. Guia dos Anfibios da Mata Atlântica: diversidade e biologia $=$ Guide to the amphibians of the Atlantic Forest: diversity and biology. São Paulo: Anolisbooks. 544 p.

HARDIN, G., 1960. The competitive exclusion principle. Science, vol. 131 , no. 3409 , p. 1292-1297. http://dx.doi.org/10.1126/ science.131.3409.1292. PMid:14399717

HÖLLDOBLER, B. and WILSON, EO., 1990. The Ants. Cambridge: Belknap Press of Harvard University Press. 732 p.. http://dx.doi. org/10.1007/978-3-662-10306-7.

JAEGER, RG. and INGER, RF., 1994. Quadrat sampling. In: HEYER, WR., DONNELLY, MA., MCDIARMID, RW., HAYEK, LC. and FOSTER, MS. (Eds.). Measuring and monitoring biological diversity: standard methods for amphibians. Washington: Smithsonian Institution Press. p. 97-102.

LEVINS, R., 1968. Evolution in changing environments. Princeton: Princeton University Press. 120 p.

LIMA, AP., 1998. The effects of size on the diets of six sympatric species of post metamorphic litter anurans in central Amazonia. Journal of Herpetology, vol. 32, no. 3, p. 392-399. http://dx.doi. org/10.2307/1565453.

MACARTHUR, R. and LEVINS, R., 1967. The limiting similarity, convergence, and divergence of coexisting species. American Naturalist, vol. 101, no. 921, p. 377-385. http://dx.doi. org/10.1086/282505.

MARTINS, ACJS., KIEFER, MC., SIQUEIRA, CC., VAN SLUYS, M., MENEZES, VA. and ROCHA, CFD., 2010. Ecology of Ischnocnema parva (Anura: Brachycephalidae) at the Atlantic rainforest of Serra da Concórdia, state of Rio de Janeiro, Brazil. Zoologia, vol. 27, no. 2, p. 201-208. http://dx.doi.org/10.1590/ S1984-46702010000200007.

MENIN, M., ROSSA-FERES, DC. and GIARETTA, AA., 2005. Resource use and coexistence of two syntopic hylid frogs (Anura, Hylidae). Revista Brasileira de Zoologia, vol. 22, no. 1, p. 61-72. http://dx.doi.org/10.1590/S0101-81752005000100008.

PIANKA, ER., 1973. The structure of lizard communities. Annual Review of Ecology and Systematics, vol. 4, no. 1, p. 53-74. http:// dx.doi.org/10.1146/annurev.es.04.110173.000413.

PIANKA, ER., 1994. Evolutionary ecology. 5th ed. New York: Harper Collins College Publishers. 486 p. 
PIMENTEL LIMA, A. and MAGNUSSON, WE., 1998. Partitioning seasonal time: interactions among size, foraging activity and diet in leaf litter frogs. Oecologia, vol. 116, no. 1-2, p. 259-266. http:// dx.doi.org/10.1007/s004420050587.

POWELL, R., PARMERLEE, JS., RICE, MA. and SMITH, DD., 1990. Ecological observations on Hemidactylus brookihaitianus Meerwarth (Sauria: Gekkonidae) from Hispaniola. Caribbean Journal of Science, vol. 26, p. 67-70.

SABAGH, LT., FERREIRA, VL. and ROCHA, CFD., 2010. Living together, sometimes feeding in a similar way: the case of the syntopic hylid frogs Hypsiboas raniceps and Scinax acuminatus (Anura: Hylidae) in the Pantanal of Miranda, Mato Grosso do Sul State, Brazil. Brazilian journal of biology $=$ Revista brasileira de biologia, vol. 70, no. 4, p. 955-959. http://dx.doi.org/10.1590/ S1519-69842010000500006. PMid:21180899

SABAGH, LT., MELLO, RS. and ROCHA, CFD., 2012. Food niche overlap between two sympatric leaf-litter frog species from Central Amazonia. Zoologia, vol. 29, no. 1, p. 95-98. http://dx.doi. org/10.1590/S1984-46702012000100013.

SANTOS-PEREIRA, M., CANDATEN, A., MILANI, D., OLIVEIRA, FB., GARDELIN, J. and ROCHA, CFD., 2011. Seasonal Variation in the Leaf-Litter Frog Community (Amphibia: Anura) from an Atlantic Forest Area in Salto Morato Natural Reserve, Southern Brazil. Zoologia, vol. 28, no. 6, p. 755-761. http://dx.doi.org/10.1590/S1984-46702011000600008.

SCHOENER, TW., 1974. Resource partitioning in ecological communities. Science, vol. 185, no. 4145, p. 27-39. http://dx.doi. org/10.1126/science.185.4145.27. PMid:17779277
SIH, A. and CHRISTENSEN, B., 2001. Optimal diet theory: when does it work, and when and why does it fail? Animal Behaviour, vol. 61, no. 2, p. 379-390. http://dx.doi.org/10.1006/anbe.2000.1592.

SIMON, MP. and TOFT, CA., 1991. Diet specialization in small vertebrates: mite-eating in frogs. Oikos, vol. 61, no. 2, p. 263-278. http://dx.doi.org/10.2307/3545344.

TAPER, ML. and MARQUET, PA., 1996. How do species really divide resources? American Naturalist, vol. 147, no. 6, p. 10721082. http://dx.doi.org/10.1086/285893.

TOFT, CA., 1980. Feeding ecology of thirteen syntopic species of anurans in a seasonal tropical environment. Oecologia, vol. 45, no. 1, p. 131-141. http://dx.doi.org/10.1007/BF00346717.

TRIPLEHORN, CA. and JOHNSON, NF., 2005. Borror and DeLong's introduction to the study of insects. 7th ed. Belmont: Thomson Brooks/Cole. 864 p.

VAN SLUYS, M. and ROCHA, CFD., 1998. Feeding habitats and microhabitat utilization by two syntopic Brazilian Amazonian frogs (Hyla minuta and Pseudo paludicula sp (gr. falcipes). Revista Brasileira de Biologia =. Brazilian Journal of Biology, vol. 58 , no. 4 , p. 559-562.

VAN SLUYS, M., ROCHA, CFD. and SOUZA, MB., 2001. Diet, reproduction and density of the leptodactylid litter frog Zachaenus parvulus in an Atlantic Rain Forest of southeastern Brazil. Journal of Herpetology, vol. 35, no. 2, p. 322-325. http:// dx.doi.org/10.2307/1566124.

ZAR, JH., 1999. Biostatistical Analysis. 4th ed. Upper Saddle River: Prentice Hall. 663 p. 